\author{
MOISES FAJARDO $^{1}$ - MANUEL MORALES ${ }^{1}$ - ESPERANZA FONTENLA ${ }^{1}$ - CLAUDIA GIORDANO ${ }^{2}$ \\ EMILIANO MORI ${ }^{3}$ - GIUSEPPE MAZZA ${ }^{4,5}$
}

\title{
SIGHTING OF SOUTHERN GREY SHRIKES PREYING ON RED PALM WEEVIL IN TWO COUNTRIES
}

\author{
${ }^{1}$ GMR Canarias, Tenerife, Canary Island. \\ ${ }^{2}$ Department of Agricultural and Food Sciences, University of Bologna, Via Fanin 50, 40127 Bologna. \\ ${ }^{3}$ Department of Life Sciences, University of Siena, Via P.A. Mattioli, 4, 53100 Siena, Italy. \\ ${ }^{4}$ CREA Research Centre for Plant Protection and Certification, via di Lanciola 12/A, I-50125 Cascine del Riccio, \\ Firenze, Italy. \\ ${ }^{5}$ Corresponding author: giuseppe.mazza@crea.gov.it
}

Fajardo M., Morales M., Fontenla E., Giordano C., Mori E., Mazza G. - Sighting of Southern Grey Shrikes preying on Red Palm Weevil in two countries.

Rhynchophorus ferrugineus, commonly known as Red Palm Weevil, is one of the most destructive and invasive palm pests' species in the world. The most important host species are coconut palms, oil palms, Canary Island palms and it is considered as a key pest in date palms crops. As the existing chemical - based treatments are not efficient, the ecofriendly biological control methods have now attracted high interest. In this note, we report for the first time the predation of the Red Palm Weevil by two subspecies of Southern Grey Shrike Lanius meridionalis, once in Spain and once in Saudi Arabia.

Key Words: diet, Lanius meridionalis, palms, Phoenix canariensis, Phoenix dactilifera, Rhynchophorus ferrugineus, Saudi Arabia, Spain.

\section{INTRODUCTION}

The Red Palm Weevil (hereafter RPW), Rhynchophorus ferrugineus (Coleoptera: Dryophthoridae), is an indigenous species to South East Asia which had recently spread worldwide mostly due to the movement of infested palms (e.g. FiABOE et al., 2012), and it is one of the most destructive and invasive pests of ornamental and economically important palms (e.g. DeMBILIO \& JAQUeS, 2015).

Currently, control methods against RPW mainly revolve around chemical treatments, but with inefficient results except for the case of Canary islands, where the RPW seems to be totally defeated (GIBLIN DAVIS et al., 2013). Moreover, chemical applications elicit serious concerns related to environmental pollution and insect resistance, in addition to human health impacts. For this reason, the ecofriendly biological control methods have now attracted high interest but they have to be developed or improved, in particular in an Integrated Pest Management point of view (e.g. Gerling et al., 2001; Fravel, 2005; Desneux et al., 2010; GIBLIN DAVIS et al., 2013).

Over 50 natural enemies have been reported to attack or negatively affect RPW (e.g. MAZZA et al., 2011; MAZZA et al. 2014) and besides the classic biocontrol agents such as bacteria, fungi and nematodes, some vertebrates (birds and mammals) are reported to feed on RPW. Some authors report that the role of these fortuitous predators against RPW is very limited and they are more a biological curiosity than a real opportunity of use (e.g. MAzzA et al., 2014). However, some recent works (BASHEER \& THOMAS, 2012; OrIHUELA-TORRES et al., 2017) show that some birds, such as the Indian Rufous Treepie Dendrocitta vagabunda parvula and the Common Kestrel Falco tinnunculus, commonly feed on this invasive pest, in India and in Spain, respectively. The same authors suggest that these birds can be used as sentinel of the presence of this invasive beetle and that further research is needed to evaluate their role as a potential pest controller.

In this note, we report for the first time the predation of the RPW by two subspecies of Southern Grey Shrike Lanius meridionalis and we update the list of birds proven to feed on RPW (Table 1).

\section{FIELD OBSERVATIONS}

During a field-inspection (24/02/2009) for the control and eradication program of the RPW in the Canary Islands, performed in El Cotillo, a coastal town in the municipality of La Oliva (North of Fuerteventura, Canary Islands) and specifically in the Finca San Martin (N 28 39'29,49' and W $\left.14^{\circ} 00^{\prime} 17,92^{\prime \prime}\right)$, an impaled female of RPW was found in one of the spines of a Phoenix canariensis palm tree (Fig. I, 1). Only 19 palms were attacked by the RPW out of 448 palms present in this area. The following days, some adults of the Canarian Southern Grey Shrike Lanius meridionalis koenigi were perched on a group of Genista scorpius; moreover, some pellets containing mainly the rest of beetles and some bones of vertebrates were found at the base of these bushes.

During a field inspection, another impaled female of RPW (Fig. I, 2) was found in Qassim (Saudi Arabia) (24/01/2018), in a highly RPW infested small farm- the specific infesting species of the area is Phoenix dactilifera (N 26 16.179 and E 4335.791). Few adults of the Aucher's Southern Grey Shrike Lanius meridionalis aucheri were perched on the Acacia trees close to the site of collection. This Shrike may be easily recognized from other co- 
Table 1 - List of birds that fed on RPW. The RPW attacked stage/s and the location/s of record were reported in addition to the references.

\begin{tabular}{cccccc}
\hline \hline Common name & Species & Family & $\begin{array}{c}\text { Attacked } \\
\text { stage (s) }\end{array}$ & $\begin{array}{c}\text { Location (s) } \\
\text { of record }\end{array}$ & Reference \\
\hline Greater Coucal & Centropus sinensis & Cuculidae & Unknown & India & FALEIRo (2006) \\
\hline Common Kestrel & Falco tinnunculus & Falconidae & Adults & Spain & OriHuELA-TorREs et al. (2017) \\
\hline Little Owl & Athene noctua & Strigidae & Adults & Italy & E. Mori, unpublished \\
\hline Canarian Grey Shrike & $\begin{array}{c}\text { Lanius meridionalis } \\
\text { koenigi }\end{array}$ & Laniidae & Adults & Spain & this article \\
\hline Arabian Grey Shrike & $\begin{array}{c}\text { Lanius meridionalis } \\
\text { aucheri }\end{array}$ & Laniidae & Adults & Saudi Arabia & this article \\
\hline Rufous Treepie & $\begin{array}{c}\text { Dendrocitta } \\
\text { vagabunda parvula }\end{array}$ & Corvidae & Adults & India & $\begin{array}{c}\text { KRISHNAKUMAR \& SUDHA (2002); } \\
\text { BASHEER \& THOMAS (2012) }\end{array}$ \\
\hline Magpie & Pica pica & Corvidae & Unknown & Italy & Lo VeRDE et al. (2008) \\
\hline Eurasian blackbird & Turdus merula & Turdidae & Unknown & Unknown & ORTEGA-GARCía et al. (2017) \\
\hline
\end{tabular}
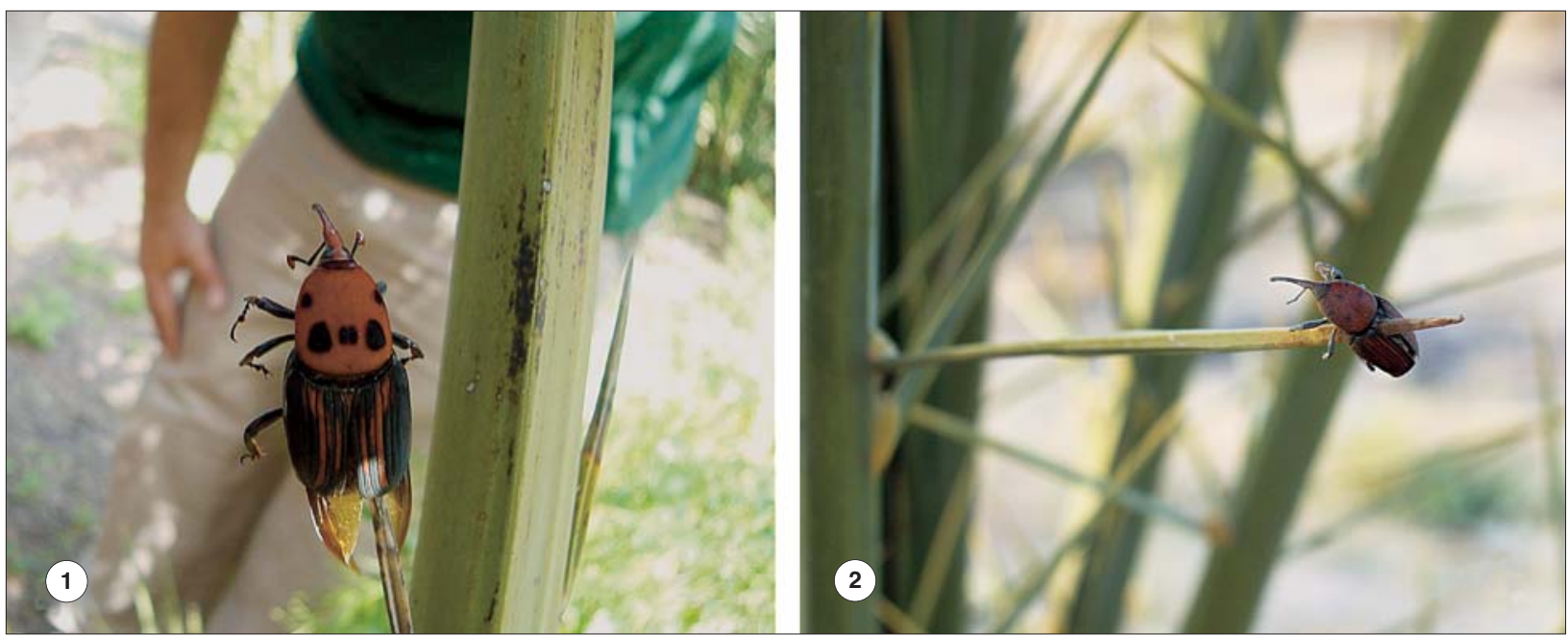

Fig. I - Impaled female of RPW found in (1) one of the spines of a Phoenix canariensis palm tree in the Finca San Martin (North of Fuerteventura, Canary Islands) and (2) Qassim (Saudi Arabia) in a Phoenix dactilifera spine.

occurring Shrikes, as it was the only Grey Shrike present in Qassim in winter, showing a deeper black face-mask and a paler beak with respect to the Mauryan Grey Shrike $L$. $m$. pallidirostris (LEFRANC \& WORFOLK, 1997).

\section{DISCUSSION}

Contributions on the Southern Grey Shrike's diet ecology are scarce and restricted to Israel (Yosef et al., 1991, BUDDEN \& Wright, 2000), Spain (e.g. HERNÁNDEZ et al., 1993) and France (LePLeY et al., 2004). In the Canary Islands, the diet of this bird is represented mainly to beetles (Curculionidae and Tenebrionidae) and lizards and the rest consist of other arthropods and vertebrates (PADILLA et al., 2005). Beetles are reported in the diet in all seasons depending on their availability, with Curculionidae selected all year round and Tenebrionidae only in warm months. PADilla et al. (2005) also report that this subspecies endemic to Canary Islands may catch insects on shrubs in addition to the ground (CRAMP \& PERRINS, 1993).

The habit of impaling prey on thorns or other sharp objects is a peculiar behavior of shrikes and it attests the presence of these birds in a certain area. Many types of thorns can be used to impale preys by these birds and, in two cases illustrated in the present communication (Table 1), the palm thorns were used to kill the RPW. The palm thorns are used by shrikes to impale ripe dates in North Africa (BEVEN \& ENGLAND, 1969) and lizards in Qatar (CogăLniceanu et al., 2015). As reported by Panov (2011) insects are usually impaled through the thorax and can remain alive for a long time. Not all the caught preys are immediately utilized by shrikes (in particular vertebrates and toxic insects) and the use of the RPW for this bird could have several functions (e.g. food supply, mate attraction during the breeding season) but this aspect needs to be explored through further research.

Recent literature reviews have highlighted the important role of insectivorous birds feeding on pest populations in different agroecosystems (e.g. MAAS et al., 2015; BARBARO et al., 2017) and the use of predatory birds as a viable alternative to pesticides or other chemical compounds to control pest insects is not a novel new (e.g. Franz, 1961). To support the evidence that shrikes may be excellent predator, the Rufous-Backed Shrike Lanius schach was introduced as biological control agent in 2011 in Indonesia, Sulawesi, in August 2011, for the management of the long horn grasshopper Sexava nubile. The operation, within 10 months after the release of the predators, showed a significant, marked downward trend concerning the insect populations and the leaf damage intensity (LALA et al., 2014). As the present communication is based just on two recorded cases, 
a specific research to further explore this hypothesis is recommended, possibly using also molecular-based tools, in order to explore the diet variability among shrike species by collecting samples (e.g. faeces or pellets) at perching sites (see GalimBerTi et al., 2013; GALIMBERTI et al., 2016). In fact, whether the predatory capacity of the Southern Grey Shrikes towards the RPW is confirmed, possible future uses of these birds in a biological control strategy might be conceived. In the areas where the Southern Grey Shrikes is already present, such as in the cited cases, it might be both used as a component of an integrated control program and as a control measure by itself.

\section{ACKNOWLEDGMENTS}

Thanks to L.G. Pârâu for the kind support. Two anonymous referees greatly improved our manuscript with their comments.

\section{REFERENCES}

Basheer P.M., Thomas S.K., 2012 - Indian Treepie Dendrocitta vagabunda parvula (Latham, 1790) (Passeriformes: Corvidae) as a natural enemy of the pests of coconut and areca palm plantations. - J. Biopest., 5: 205-208.

Barbaro L., Rusch A., Muiruri E.W., Gravellier B., Thiery D., CASTAgneyrol B., 2017 - Avian pest control in vineyards is driven by interactions between bird functional diversity and landscape heterogeneity. - J. Appl. Ecol., 54 (2): 500-508.

BEVEN G., ENGLAND M.D., 1969 - The impaling of prey by shrikes. - Br. Birds, 62: 192-199.

Budden A.E., Wright J., 2000 - Nestling diet, chick growth and breeding success in the southern grey shrike (Lanius meridionalis). In: Proceedings of the 3rd international shrike symposium, vol. 22. Ring, Gdansk, Yosef R., Lohrer F.E., Van Nieuwenhuyse D. \& Busse P. Eds., pp. 165-172.

Cogălniceanu D., Valdeón A., Gosá A., Al-Hemaidi A.A.M., CASTilla A.M., 2015 - Shrike predation on the lizard Mesalina adramitana in Qatar; a review of reported reptile and amphibian prey. QScience Connect 1 http://dx.doi.org/10.5339/connect.2015.1

Cramp S., Perrins C.M., 1993 - The birds of the Western Palearctic, Vol. VII. - Oxford University Press, New York.

DeMBILIO Ó., JAQUeS J.A., 2015 - Biology and management of red palm weevil. In: Sustainable Pest Management in Date Palm: Current Status and Emerging Challenges, W. Wakil, Faleiro J.R. \& Miller T.A., Eds. Springer International Publishing, Switzerland, pp. 13-36.

Desneux N., Wajnberg E., Wyckhuys K.A., Burgio G., Arpaia S., Narváez-Vasquez C.A., GonZalez-Cabrera J., Catalan-Ruescas D., Tabone E., Frandon J., Pizzol J., Poncet C., Cabello T., Urbaneja A., 2010 Biological invasion of European tomato crops by Tuta absoluta: ecology, geographic expansion and prospects for biological control. - J. Pest Sci. 83(3): 197-215.

FALEIRO J.R., 2006 - A review of the issues and management of the red palm weevil Rhynchophorus ferrugineus (Coleoptera: Rhynchophoridae) in coconut and date palm during the last one hundred years. - Int. J. Trop. Insect Sci., 26: 135-154.

Fiaboe K.K.M., Peterson A.T., Kairo M.T.K., Roda A.L.,
2012 - Predicting the potential worldwide distribution of the red palm weevil Rhynchophorus ferrugineus (Olivier) (Coleoptera: Curculionidae) using ecological niche modeling. - Florida Entomologist, 95: 659-673.

FRANZ J.M., 1961 - Biological control of pest insects in Europe. - Annu. Rev. Entomol., 6 (1): 183-200.

FraVEL D.R., 2005 - Commercialization and implementation of biocontrol. - Annu. Rev. Phytopathol., 43: 337-359.

Galimberti A., De Mattia F., Losa A., Bruni I., Federici S., Casiraghi M., Martellos S., Labra M., 2013 - DNA barcoding as a new tool for food traceability. - Food Research Intern., 50(1): 55-63.

Galimberti A., Spinelli S., Bruno A., Mezzasalma V., De Mattia F., Cortis P., LABra M., 2016 - Evaluating the efficacy of restoration plantings through DNA barcoding of frugivorous bird diets. - Cons. Biol., 30(4): 763-773.

Gerling D., Alomar O., Arnò J., 2001 - Biological control of Bemisia tabaci using predators and parasitoids. Crop Protect., 20(9): 779-799.

Giblin-Davis R.M., Faleiro J.R., Jacas J.A., PeÑa J.E., VIDYASAGAR P.S.P.V., 2013 - Biology and management of the red palm weevil, Rhynchophorus ferrugineus. - In: Potential Invasive Pests of Agricultural Crops. PEÑA J.E., Ed., CABI, Wallingford, United Kingdom, pp. 1-34.

Hernández A., 1993 - Biologia de la familia Laniidae (alcaudón real Lanius excubitor L., alcaudón dorsirrojo Lanius collurio L., y alcaudón común Lanius senator L.) en la cuenca del rio Torío, provincia de León. $\mathrm{PhD}$ thesis, Universidad de Castilla-León, León.

Krishnakumar R., Sudha G., 2002 - Indian tree pie Dendrocitta vagabunda parvula (Whistler and Kinnear) (Corvidae). A predatory bird of red palm weevil Rhynchophorus ferrugineus (Oliv.). - Insect Environment, 8: 133.

Lala F., Wagiman F.X., Putra N.S., 2014 - The introduction impact of predatory bird Lanius schach Linn. on population of long horn grasshopper Sexava nubila Stal. and leaves damage of coconut. - J. Agric. Biol. Sci., 9(2): 71-75.

LeFranc N., Worfolk T., 1997 - Shrikes - A guide to the shrikes of the world. Pica Press Sussex, UK.

Lepley M., Thevenot M., Guillaume C. P., Ponel P., BAYle P., 2004 - Diet of the nominate Southern Grey Shrike Lanius meridionalis meridionalis in the north of its range (Mediterranean France). Bird Study, 51(2): 156162.

Lo Verde G., Caldarella C.G., La Mantia G., Sauro G., 2008 - Punteruolo rosso delle palme, l'emergenza continua. Informatore Agrario, 64: 74-77.

Maas B., Tscharntke T., Saleh S., Dwi-Putra D., Clough Y., 2015 - Avian species identity drives predation success in tropical cacao agroforestry. - J. Appl. Ecol., 52: 735-743.

Mazza G., Cini A., Cervo R., Longo S., 2011 - Just phoresy? Reduced lifespan in red palm weevils Rhynchophorus ferrugineus (Coleoptera: Curculionidae) infested by the mite Centrouropoda almerodai (Uroactiniinae: Uropodina). - Ital. J. Zool., 78 (1): 101105.

Mazza G., Francardi V., Simoni S., Benvenuti C., Cervo R., Faleiro J.R., Llacer E., LONGO S., NANNelli R., TARASCO E., ROvERSI P.F., 2014 - An overview on the natural enemies of Rhynchophorus palm weevils, with focus on R. ferrugineus. - Biol. Control, 77: 83-92.

Orinuela-Torres A., Perales P., Rosado D., PérezGARCía J.M., 2017 - Feeding ecology of the Common 
Kestrel Falco tinnunculus in the south of Alicante (SE Spain). Rev. Catalana Ornitol., 33: 10-16.

Ortega-García L., Tabone E., Beaudoin-Ollivier L., Ment D., Buradino M., Jaques J.A., Garrido-Jurado

I., Dembilio O., Moraga E.Q., 2017 - Natural Enemies of Rhynchophorus ferrugineus and Paysandisia archon. In: Handbook of Major Palm Pests: Biology and Management. Soroker V. \& Colazza S., Eds. John Wiley \& Sons. p. 171-186

Padilla D.P., Nogales M., Perez M., Perez A.J., 2005 -
Seasonal diet of an insular endemic population of Southern Grey Shrike Lanius meridionalis koenigi in Tenerife, Canary Islands. - Ornis Fennica, 82(4): 155165.

PANOV E.N., 2011 - The true shrikes (Laniidae) of the world: ecology, behavior and evolution. Pensoft, SofiaMoscow.

Yosef R., Mitchell W.A., Pinshow B., 1991 - The proximate costs and benefits of polygyny to male northern shrike. - Wilson Bulletin 103: 146-149. 